Journal of Extension Education

Vol. 29 No. 3, 2017

DOI:https://doi.org/10.26725/JEE.2017.3.29.5892-5901

\title{
Training Need Assessment on Communication Competencies of Extensionists working in Krishi Vigyan Kendras (Farm Science Centres)
}

\author{
Jagriti Rohit ${ }^{1}$ and C.N. Anshida Beevi ${ }^{2}$
}

\begin{abstract}
Training need assessment has always been an important area in the designing the capacity development programme for the extensionists. It helps to make the extensionists updated, upgraded and competent in their field. Training need using Borich Need Assessment Model was carried out in the four zones of Krishi Vigyan Kendras (KVK) to assess the communication competencies of the extensionists. The zones of KVKs were selected using simple random sampling without replacement method. From each zone, $20 \mathrm{KVK}$ s were selected randomly and 3 extensionists from each KVK were selected by using simple random sampling technique. The total sample size was 240. Mean weighted discrepancy score (MWDS) was used to study the training needs. The results of the study indicated that the highest level of training need was expressed in their ability to use computer (Internet) and PowerPoint presentation followed by their "ability to prepare visual aids to help deliver information" while lowest mean weighted discrepancy score was given to their ability in presenting the seminar. Kruskal wallis test was carried out to find the differences among the zones of KVK. Attention should be given to designing inservice training programmes which can adequately address the present training needs of the extensionists.
\end{abstract}

Keywords : Extensionists; Krishi Vigyan Kendra; Kruskal-Wallis test; Training Need; Borich Need Hierarchy;

\section{INTRODUCTION}

Agriculture holds an important place in the Indian economy and currently India is among the top two agricultural producers in the world. Though agriculture employs about 51 per cent of the total work force, its contribution towards Gross Domestic Product is merely 11.8 per cent (Agricultural Statistics at a Glance, 2014). India saw remarkable progress in food production which has increased four folds in the last six decades. Policy, research and extension support are among the various drivers which helped to attain this herculean task. In agricultural development, extension and advisory services play a vital role for nutritional security, food sovereignty, and

1 \& 2. Scientists, ICAR- Central Research Institute for Dryland Agriculture, Hyderabad-500059. 
Training Need Assessment on Communication Competencies of Extensionists working in Krishi Vigyan Kendras

(Farm Science Centres)

economic stability. In order to contribute better towards agricultural development, these extension and advisory need new capacities to confront the present challenges in agriculture.

Agricultural extension is said to be a public service for human resource development of people engaged in agriculture including farmers. Along with development of the clientele, extension professionals need to be upgraded and updated with the existing and new skills. Success of an organization is directly related to the skill of its human resource. Competent human resources are the valuable assets to the extension organization. Farm extension services have reaffirmed their essential role in agrarian development, poverty reduction and rural prosperity (Birner and Anderson, 2007). The ability of extension professionals to design, develop, deliver and evaluate extension programmes determines the effectiveness of an extension organization as they are directly responsible to the people. Their ability to perform extension tasks is generally said to be a function of their job competencies. Communication skill is an important component of the professional competencies. Communication competencies assume a greater role in agricultural extension. Extension professionals need to be efficient in communicating with the farmers so that latest technologies and information is provided to them. Communication competency may be defined as the ability to listen and to communicate effectively orally and in writing. Effective and efficient communication of farm information is an important pre-requisite for affecting adoption of agricultural innovations. The extension workers as communicators of farm information became an indispensable element in the process of communication in implementing and securing desired change in agriculture. The development in agriculture depends on communication. Thus, there is need to understand training needs of extension personnel in communication competencies.

Competency of extension professionals can be enhanced by providing training opportunities that are focused on areas related to competency (Mitchell, 2002). Cyr (2008) showed that the extension functionaries enhanced their facilitation competency by participating in the training.

In this scenario, the present study is an attempt to identify and prioritize the communication training needs of extensionists, so that necessary measures would be suggested to develop suitable capacity building modules and conduct capacity enhancement programmes for them.

\section{METHODOLOGY}

Krishi Vigyan Kendras (KVKs) were selected purposively as an organization for the present study due to the immense importance given to them in providing 
extension services to the farmers. Four KVK zones selected were

1. Zone I: Delhi, Haryana, Jammu and Kashmir, Himachal Pradesh, and Punjab

2. Zone II: Bihar, Jharkhand, West Bengal and Andaman and Nicobar

3. Zone IV: Uttar Pradesh and Uttarakhand

4. Zone VII: Chhattisgarh, Madhya Pradesh and Odisha

From each zone, twenty ICARKVKs and three extensionists from each KVK were selected following simple random sampling technique. Hence, the total sample size was 240. An extensionist, for the present study, was operationalized as an extension professional having acquired a specialised degree in agricultural sciences or allied sciences, working in Krishi Vigyan Kendras and directly in contact with the clientele/ farmers. Extensionists can be synonymously used for subject matter specialist in Krishi Vigyan Kendra.

Communication competency was operationalized as ability of extension professionals to delivering radio talks, establishing rapport with the farmers, visual aids prepration to help deliver information, use computer (internet) and power point presentation, convey extension messages effectively, presentation in seminars, persuade farmers to adopt technologies, write effectively for target audience, provide feedback of researchable problems to researchers and delivering TV talks. The questionnaire comprising these ten items was administered to the sample respondents.

Training need is operationalized in this study as the difference in the skills expected or required by extensionists in their job and the actual skills possessed by them. The present study adopted the Borich Need Assessment Model (Borich, 1980) which relies on the extension agents' judgments about their own performances. A dichotomous importance $v$ s possessed competency five point continuums, from least important to most important and very low to very high was developed. A score of 1 on the scale signified the least important competency/very low possession and number 5 denoted the most important competency/very high possession. The extensionists were asked to give their self-perceived responses on the identified 10 communication competency statements for both importance and possessed competency. Reliability as a measure of internal consistency was established using Cronbach's alpha and the values were 0.864 for the importance level and 0.835 for the competence level.

Discrepancy Score $=\mathrm{I}-\mathrm{C}$ Weight Discrepancy Score $=$ I $(\mathrm{I}-\mathrm{C})$ Mean Weight Discrepancies Scores $=\Sigma$ I (I-C) / n 
Training Need Assessment on Communication Competencies of Extensionists working in Krishi Vigyan Kendras

(Farm Science Centres)

In the above equations, FINDINGS AND DISCUSSION I is Importance level, $\mathrm{C}$ is Personal Profile of Extensionists Competency level and $\mathrm{n}$ is number of extensionists.

The personal profile of the extensionists is presented in Table 1.

Table 1.

Personal Profile of the Extensionists

$n=240$

\begin{tabular}{|c|c|c|c|c|}
\hline $\begin{array}{l}\text { S1. } \\
\text { No. }\end{array}$ & Variables & Category & Frequency & Percentage \\
\hline \multirow{3}{*}{1.} & \multirow{3}{*}{ Age } & $<35$ & 48 & 17.5 \\
\hline & & $35-50$ & 150 & 62.5 \\
\hline & & $>50$ & 52 & 20.0 \\
\hline \multirow{2}{*}{2.} & \multirow{2}{*}{ Gender } & Male & 157 & 65.4 \\
\hline & & Female & 83 & 34.6 \\
\hline \multirow{3}{*}{3.} & \multirow{3}{*}{ Experience } & $1-10$ years & 81 & 33.8 \\
\hline & & 11-21 years & 93 & 38.8 \\
\hline & & $>21$ years & 66 & 27.5 \\
\hline \multirow{2}{*}{4.} & \multirow{2}{*}{ Education } & Post-graduation & 75 & 31.3 \\
\hline & & Ph.D. & 165 & 68.7 \\
\hline \multirow{2}{*}{5.} & \multirow{2}{*}{ Position } & Subject matter specialist & 177 & 73.8 \\
\hline & & Programme coordinator & 63 & 26.3 \\
\hline \multirow{3}{*}{6.} & \multirow{3}{*}{ Type of $K V K$} & ICAR & 69 & 28.8 \\
\hline & & SAU & 129 & 53.8 \\
\hline & & $\mathrm{NGO}$ & 42 & 17.5 \\
\hline
\end{tabular}

\section{Training Need Assessment}

The results of the training need analysis for communication competencies based on mean weighted discrepancy score are depicted in Table 2. The highest mean weighted discrepancy score (5.044) was accorded to the "ability to use computer (internet) and PowerPoint presentation". This means that highest training need is in the use of computer and internet is perceived by the respondents. As computers and ICT have become indispensible part of work culture, the extensionists felt the need to get training in these areas. Okeowo (2015) also laid emphasis on training in the field of ICT in agriculture for the extension agents. Visual aids are important tools to communicate with the rural people. It is very effective even with the illiterate masses. So, the extensionists felt the need to enhance their abiltiy to prepare different types 
of visual aids. The third rank in the perceived training need was "ability to convey extension method effectively" (MWDS 5.012). Extension professionals need to build good relationships and rapport with farmers so as to enable the later to develop trust and confidence of the extension professionals. The lowest rank on the training need assessment was given to their ability to present a seminar (MWDS 2.659). Majority of the extensionists had Ph.D. as their highest degree and so they were well versed in their subject. It helped them to prepare and present seminar well.

Table 2.

Training Need Analysis for Communication Competencies

\begin{tabular}{|c|c|c|c|c|c|c|c|}
\hline \multirow{2}{*}{$\begin{array}{l}\text { S1. } \\
\text { No. }\end{array}$} & \multirow{2}{*}{ Competencies } & \multicolumn{2}{|c|}{$\begin{array}{c}\text { Level of } \\
\text { Possession }\end{array}$} & \multicolumn{2}{|c|}{$\begin{array}{c}\text { Level of } \\
\text { Importance }\end{array}$} & \multirow{2}{*}{ MWDS } & \multirow[t]{2}{*}{ Rank } \\
\hline & & Mean & $\begin{array}{l}\text { Std } \\
\text { dev }\end{array}$ & Mean & $\begin{array}{l}\text { Std } \\
\text { dev }\end{array}$ & & \\
\hline 1. & Delivering radio talks & 2.966 & 0.683 & 4.179 & 0.514 & 3.601 & IX \\
\hline 2. & $\begin{array}{l}\text { Establishing rapport with the } \\
\text { farmers }\end{array}$ & 3.195 & 0.707 & 4.358 & 0.530 & 3.708 & VII \\
\hline 3. & $\begin{array}{l}\text { Ability to prepare visual aids } \\
\text { to help deliver information }\end{array}$ & 2.728 & 0.705 & 4.320 & 0.485 & 5.039 & II \\
\hline 4. & $\begin{array}{l}\text { Ability to use computer } \\
\text { (Internet) and Power Point } \\
\text { presentation }\end{array}$ & 2.539 & 0.909 & 4.416 & 0.579 & 5.044 & I \\
\hline 5. & $\begin{array}{l}\text { Ability to convey extension } \\
\text { messages effectively }\end{array}$ & 3.1 & 0.707 & 4.725 & 0.456 & 5.012 & III \\
\hline 6. & Ability to present in seminar & 3.237 & 0.657 & 4.058 & 0.553 & 2.659 & $X$ \\
\hline 7. & $\begin{array}{l}\text { Ability to persuade farmers to } \\
\text { adopt technologies }\end{array}$ & 3.004 & 0.705 & 4.570 & 0.504 & 4.7 & IV \\
\hline 8. & $\begin{array}{l}\text { Effective writing for target } \\
\text { audience }\end{array}$ & 2.616 & 0.745 & 4.033 & 0.516 & 3.693 & VIII \\
\hline 9. & $\begin{array}{l}\text { Provide feedback of } \\
\text { researchable problems to } \\
\text { researchers }\end{array}$ & 3.087 & 0.729 & 4.341 & 0.500 & 3.875 & V \\
\hline 10. & Delivering TV talks & 2.929 & 0.690 & 4.212 & 0.680 & 3.760 & VI \\
\hline
\end{tabular}


Training Need Assessment on Communication Competencies of Extensionists working in Krishi Vigyan Kendras (Farm Science Centres)

\begin{tabular}{|c|c|c|c|c|c|c|}
\hline \multirow[t]{2}{*}{ 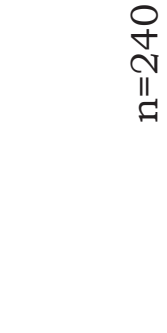 } & 官 & & $\begin{array}{l}\text { ri } \\
\text { ம் }\end{array}$ & $\begin{array}{l}0 \\
m \\
-!\end{array}$ & ○ & 齐 \\
\hline & 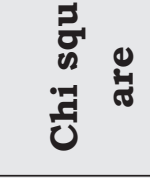 & 苝 & 苟 & กै & $\begin{array}{l}* \\
* \\
n \\
m \\
\infty \\
\infty \\
m\end{array}$ & 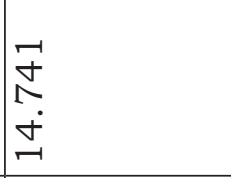 \\
\hline \multirow{10}{*}{ 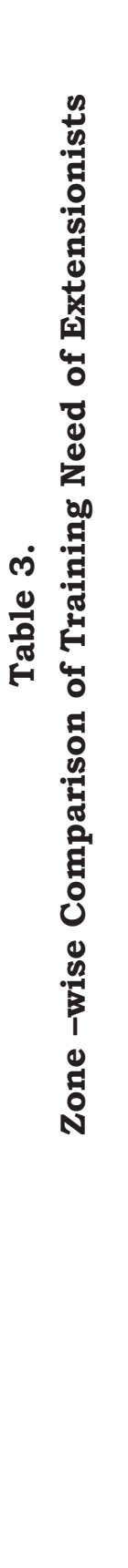 } & \multirow{2}{*}{ 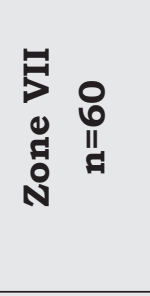 } & 范范 & $\begin{array}{l}\text { N } \\
\text { N } \\
\text { i } \\
\end{array}$ & $\begin{array}{l}a \\
i \\
i \\
\end{array}$ & $\begin{array}{l}n \\
\dot{\sim} \\
\text { cं }\end{array}$ & $\begin{array}{l}\infty \\
\sigma \\
\sim \\
\sim\end{array}$ \\
\hline & & 吕 & $\begin{array}{l}m \\
\stackrel{\sigma}{r}\end{array}$ & $\begin{array}{l}\text { 누 } \\
\text { ஸे }\end{array}$ & $\begin{array}{l}\dot{\theta} \\
\dot{q}\end{array}$ & $\begin{array}{l}0 \\
10 \\
\text { ம் }\end{array}$ \\
\hline & \multirow{2}{*}{$\begin{array}{ll}B & 0 \\
0 & \emptyset \\
\text { İ } & \| \\
\text { ㅇ } & \end{array}$} & 茪宫 & $\begin{array}{l}n \\
\dot{\sigma} \\
\dot{\alpha}\end{array}$ & $\begin{array}{l}0 \\
n \\
\text { N } \\
\end{array}$ & $\begin{array}{l}\text { N } \\
n \\
\text { N } \\
\end{array}$ & $\begin{array}{l}m \\
1 \\
i n \\
\text { n } \\
\end{array}$ \\
\hline & & $\begin{array}{l}0 \\
0 \\
11 \\
11\end{array}$ & $\begin{array}{l}n \\
\dot{n} \\
\dot{n}\end{array}$ & $\begin{array}{l}0 \\
0 \\
\dot{0}\end{array}$ & $\begin{array}{l}0 \\
\text { mे. } \\
\dot{\gamma}\end{array}$ & $\begin{array}{l}\infty \\
1 \\
n \\
n\end{array}$ \\
\hline & \multirow{2}{*}{ 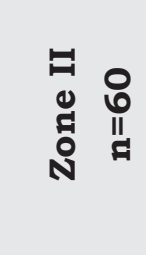 } & 苑 & $\begin{array}{l}m \\
i n \\
\sim \\
\dot{N}\end{array}$ & $\begin{array}{l}\infty \\
1 \\
\sim \\
\sim \\
\end{array}$ & $\begin{array}{l}\infty \\
+ \\
\sim \\
\end{array}$ & $\begin{array}{l}\circ \\
0 \\
\text { n் } \\
\end{array}$ \\
\hline & & 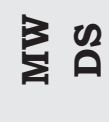 & $\begin{array}{l}0 \\
\stackrel{1}{1} \\
\dot{8}\end{array}$ & $\begin{array}{l}\vec{N} \\
\text { nे }\end{array}$ & $\begin{array}{l}\infty \\
1 \\
n \\
n\end{array}$ & $\begin{array}{l}\infty \\
\infty \\
\dot{n}\end{array}$ \\
\hline & \multirow{2}{*}{ 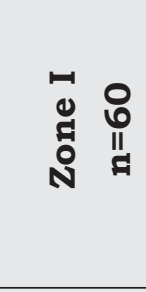 } & 茪苋 & $\begin{array}{l}\text { मे } \\
\text { ले } \\
\text { ले }\end{array}$ & $\begin{array}{c}\infty \\
\stackrel{+}{\sim} \\
\dot{\sim}\end{array}$ & $\begin{array}{l}a \\
i n \\
m \\
i \\
i\end{array}$ & $\begin{array}{l}\stackrel{+}{N} \\
\text { n் }\end{array}$ \\
\hline & & 完 & $\begin{array}{l}\stackrel{0}{1} \\
\dot{n}\end{array}$ & $\begin{array}{l}\stackrel{\leftrightarrow}{N} \\
\stackrel{+}{+}\end{array}$ & $\begin{array}{l}0 \\
\dot{\gamma} \\
\dot{m}\end{array}$ & $\begin{array}{l}10 \\
10 \\
10 \\
4\end{array}$ \\
\hline & 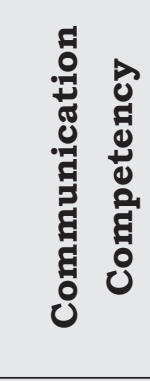 & & 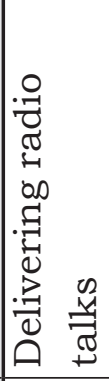 & 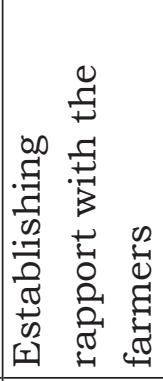 & 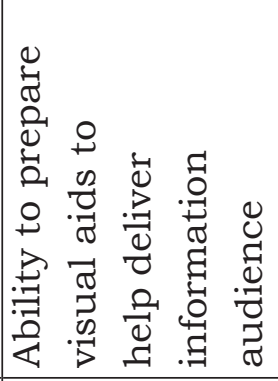 & 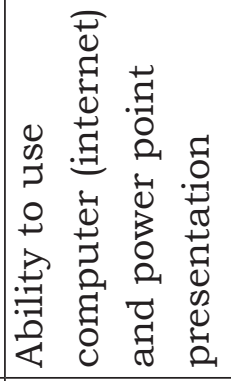 \\
\hline & $\dot{\nabla} \stackrel{0}{\circ}$ & & - & $\dot{N}$ & $\dot{n}$ & $\dot{\sigma}$ \\
\hline
\end{tabular}


Journal of Extension Education

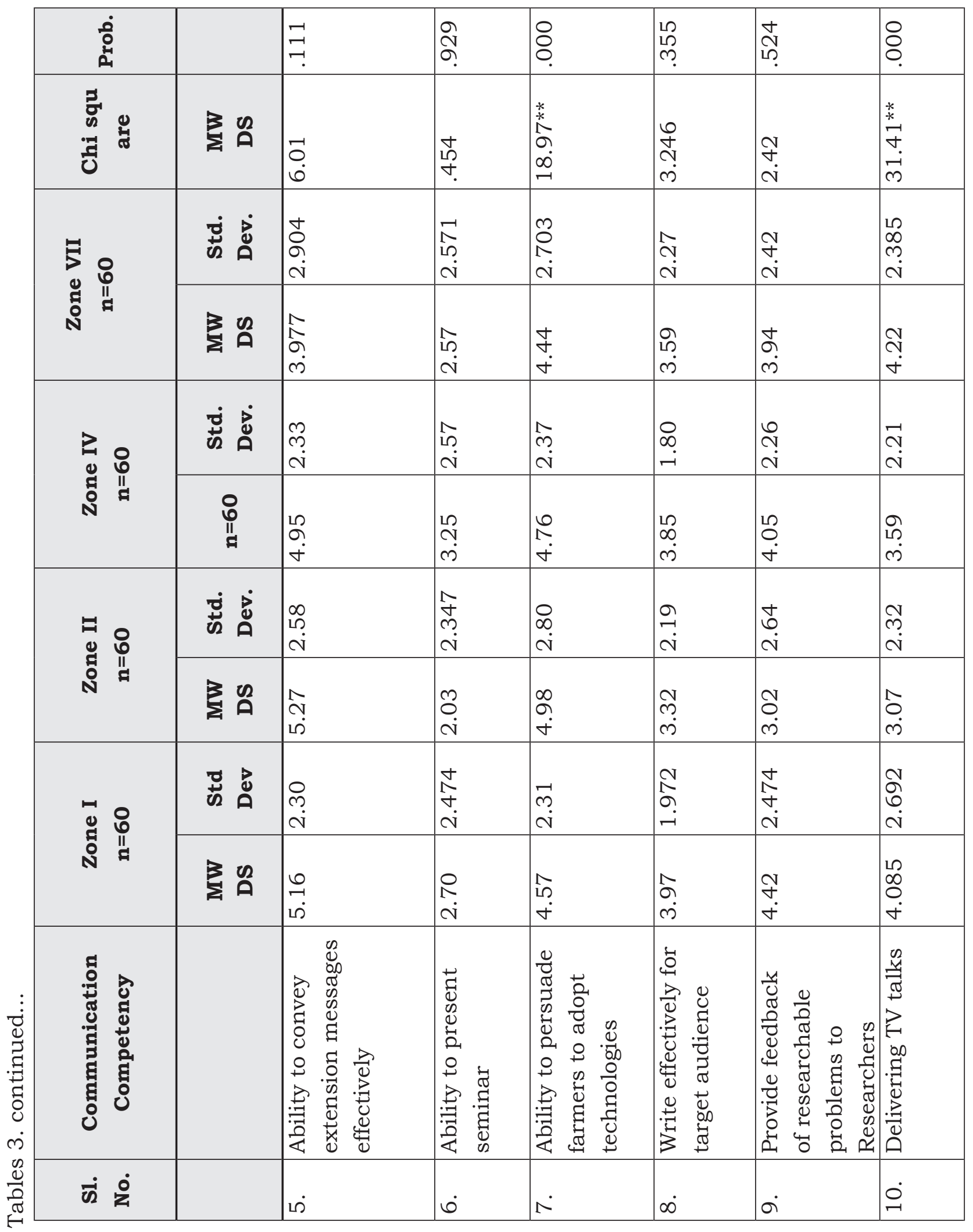


Training Need Assessment on Communication Competencies of Extensionists working in Krishi Vigyan Kendras

(Farm Science Centres)

A comparison among the training needs of extensionists in the selected Zones of KVK was studied using Kruskal Wallis test statistics and depicted in Table 3. Out of 8 competencies statements, a significant difference was observed in training needs among extensionists in the selected Zones of $\mathrm{KVK}$ on the following competencies statements; Ability to prepare visual aids to help deliver information and write effectively for target audience, ability to use computer(Internet) and PowerPoint presentation (chi-square 14.741 at 0.05 level of significance), ability to persuade farmers to adopt technologies (chisquare 18.997 at 0.01 level of significance), delivering TV talks (chi-square 31.417 at 0.01 level of significance).

Training need for communication competency was assessed based on the gender of the extension professionals (Table 4). "Ability to convey extension messages effectively" was accorded the highest MWDS for both male (MWDS 5.033) and female (MWDS 5.045) extensionists respectively. While the second rank for the perceived training need was given to "ability to persuade farmers to adopt technologies" for both male and female extensionists. "Ability to use computer (internet) and PowerPoint presentation" was ranked third (MWDS 4.117) for the female extensionists whereas it was accorded sixth rank in terms of MWDS (3.781) by the male extensionists. The third highest MWDS (3.925) for the male extensonists was delivering TV talks. The lowest rank for both male and female extensionists was their ability to present in seminars.

Table 4.

Comparison of Training Need Between Male and Female Extensionists

\begin{tabular}{|c|l|c|c|c|c|}
\hline $\begin{array}{c}\text { S1. } \\
\text { No. }\end{array}$ & \multicolumn{1}{|c|}{$\begin{array}{c}\text { Communication } \\
\text { Competency }\end{array}$} & $\begin{array}{c}\text { Female } \\
\mathbf{n = 8 3} \\
\text { (MWDS) }\end{array}$ & Rank & $\begin{array}{c}\text { Male } \\
\mathbf{n = 1 7 7} \\
\text { (MWDS) }\end{array}$ & Rank \\
\hline 1. & Delivering radio talks & 3.928 & VI & 3.417 & IX \\
\hline 2. & $\begin{array}{l}\text { Establishing rapport with the } \\
\text { farmers }\end{array}$ & 3.736 & VIII & 3.703 & VII \\
\hline 3. & $\begin{array}{l}\text { Ability to prepare visual aids } \\
\text { to help deliver information to } \\
\text { audience }\end{array}$ & 4.064 & IV & 3.830 & V \\
\hline 4. & $\begin{array}{l}\text { Ability to use computer } \\
\text { (internet) and power point } \\
\text { presentation }\end{array}$ & 4.117 & III & 3.781 & VI \\
\hline
\end{tabular}


Journal of Extension Education

\begin{tabular}{|c|c|c|c|c|c|}
\hline 5. & $\begin{array}{l}\text { Ability to convey extension } \\
\text { messages effectively }\end{array}$ & 5.045 & I & 5.033 & I \\
\hline 6. & Ability to present in seminar & 2.688 & $\mathrm{X}$ & 2.640 & $\mathrm{X}$ \\
\hline 7. & $\begin{array}{l}\text { Ability to persuade farmers to } \\
\text { adopt technologies }\end{array}$ & 4.700 & II & 4.709 & II \\
\hline 8. & $\begin{array}{l}\text { Write effectively for target } \\
\text { audience }\end{array}$ & 4.052 & $\mathrm{~V}$ & 3.516 & VIII \\
\hline 9. & $\begin{array}{lcc}\text { Provide feedback } & \text { of } \\
\text { researchable problems } & \text { to } \\
\text { Researchers } & & \\
\end{array}$ & 3.829 & VII & 3.894 & IV \\
\hline 10. & Delivering TV talks & 3.446 & IX & 3.925 & III \\
\hline
\end{tabular}

\section{CONCLUSION}

Communication being one of the core competencies is vital for overall professional competency of the extensionists. The extension professionals should be able to communicate effectively with their clientele to improve their efficiency at job. These differences in the competency levels could be attributed due to the lack of in-service training programmes. The approaches and practices of delivering extension services are consistently evolving and curriculum of training institutions being improved based on new developments. The communication training need to be further analyzed in terms of depth, content and scope for improvement. The in-service training should be systematized and regularized or at least the frequency of in-service training should be increased in the future so that communication skills of extension agents in the field are consistently upgraded and their confidence levels on communication competencies further enhanced.

\section{REFERENCES}

Agricultural Statistics at a Glance. (2014). Ministry of Agriculture, Government of India. New Delhi. Oxford University Press. Retrieved from http://eands. dacnet.nic.in/PDF/AgriculturalStatistics-At-Glance2014.pdf

Birner, R. \& Anderson, J. R. (2007). How to make agricultural extension demand driven? The case of India's agricultural extension policy. International Food Policy Research Institute, 729.

Borich, G. D. (1980). A needs assessment model for conducting follow-up studies. Journal of Teacher Education, 31(3), 39-42.

Cyr, L. F. (2008). Facilitation competence: A catalyst for effective extension work. Journal of Extension, 46(4). 
Mitchell, B.O. (2002). Core Competencies for the cooperative extension system. Executive Report, Sub-competencies Study. Administrative County Leaders. North Carolina Cooperative Extensions, P. 20.

Nath, Dipak., Jain, P. K., Talukdar, R. K \& Hansra, B.S. (2016). Constraints encountered by the beneficiaries of
Krishi Vigyan Kendra in North Eastern region of India, Journal of Extension Education. 28(2), 5665-5668.

Okeweo, A.T. (2015). Analysis of competency and training needs among agricultural extension personnel in Lagos State, International Journal of Forestry and Horticulture. 1(2), 14-21 